\title{
EMÉRITA BRASILIENSE
}

\author{
Adriana Rouanet Bassi *
}

Professora emérita, Bárbara Freitag-Rouanet. Minha mãe. Quando recebi o convite para a cerimônia, à qual infelizmente não pude comparecer por morar em Londres, decidi procurar a definição exata de "emérita" no dicionário Aurélio. Sabia que a palavra derivava do latim emeritus, mas queria saber um pouco mais sobre seu uso no português. Nosso caro Aurélio me decepcionou. Ele define "emérita" como: "1. Gênero de pequenos crustáceos decápodes, anomuros, vastamente distribuídos pelas praias arenosas das costas da América do Norte, e pelas costas ocidentais da América do Sul. 2. Qualquer espécie desse gênero, como, por exemplo, a Emerita brasiliense, vulgarmente conhecida como tatuí’.

Quando li estas definições, lembrei-me de meu pai, não por ele ser um crustáceo, apesar de ser também uma espécie rara, mas porque, quando eu era pequena, nós jogávamos uma variação de um jogo surrealista chamado "cadavre exquis", em que uma pessoa pensa em dez palavras e a outra, sem saber quais são, escreve dez definições. O genial, é que as definições sempre acabam descrevendo bem as palavras! Olhei novamente para as definições de "emérita". Minha mãe poderia ser vista como um pequeno crustáceo? Talvez. Ela é rápida e consistente como um siri, deliciosa como uma lagosta, além de adorar o mar e de ter antenas afiadíssimas. Mas, de alguma forma, esta definição não fazia justiça a Bárbara Freitag, minha mãe. Olhei para a segunda definição. "Qualquer espécie desse gênero, como, por exemplo, a Emerita brasiliense, vulgarmente conhecida como tatuí”. Pelo jeito, minha mãe continuaria a ser do gênero dos crustáceos, mas não seria qualquer um, seria a emérita brasiliense! Ah! Finalmente uma definição que descreve minha mãe. Apesar de

Assessora de Assuntos Culturais da Embaixada do Brasil em Londres. 
ser alemã, ela viveu mais de 30 anos em Brasília, dedicando-se à universidade que hoje a homenageia. Não há dúvida, portanto, que ela seja uma emérita brasiliense.

Mas o Aurélio não é capaz de definir minha mãe. Pois como se define alguém que consegue, ao mesmo tempo, ser mãe dedicada e carinhosa, esposa apaixonada e companheira, irmã atenciosa, avó brincalhona, embaixatriz elegante, professora carismática e estimuladora, e, agora, acadêmica emérita? Talvez a definição do Aurélio ainda possa ser aproveitada, pois só um decápode poderia carregar tantas responsabilidades com graça e facilidade. Seja como for, sei que ela é muito especial e, sem dúvida, a única de sua espécie. Parabéns, Mami. 